\title{
THE IMPACT OF CHANGES IN MILITARY EXPENDITURES ON THE WASHINGTON STATE ECONOMY
}

\author{
David Hughes, David Holland, and Philip Wandschneider*
}

\begin{abstract}
This study provides a better understanding of the nature and significance of military spending to the Washington State economy. The pattern of military spending on Washington-produced goods and services is summarized for the past, and simulations are made for later years. The impact on employment and income of military spending relative to other sources of demand is examined with an input/output model of the Washington economy. Estimates are made of the job growth in Washington that can be attributed to the Reagan military buildup. Three-year simulations indicate that military-generated demand is not likely to be the engine of economic growth in the state that it had been in the previous decade. Growth in the future levels of foreign exports may replace losses in income and employment as future military spending in the state declines.
\end{abstract}

\section{INTRODUCTION}

Military spending at installations throughout Washington state and nuclear weapons production at Hanford have long been recognized as important sources of income and jobs for people in Washington. Growth in military contracts for the shipbuilding and aerospace industries located in Washington has also generated increased income and employment for many years. However, there are a number of reasons for believing that future military spending will not be a major stimulus to state economic growth in the coming years.

Several factors indicate that future military budgets will not increase and may actually suffer large decreases in real terms as compared to recent spending levels. First, Gramm-Rudman budget targets will require major reductions in the large federal government budget deficit. With public sentiment against tax increases, and with uncontrollable expenses such as social insurance obligations continuing to grow as a share of overall spending, the federal government will increasingly be faced with a "guns or butter" tradeoff. Second, public support for high levels of military spending has declined, partly because of perceived waste, mismanagement, and fraud by defense contractors. Although public support was temporarily buoyed by the recent Gulf war, the postwar military spending debate seems to center more on the type of military spending than on the level of spend-

\footnotetext{
* Former post-doctoral research associate, professor, and assistant professor all in the Department of Agricultural Economics, Washington State University, Pullman, Wash. Financial support for this study was provided by the Washington State Legislature in cooperation with the Institute for Public Policy at Evergreen State College.
} 
ing. Third, the rapid change in economic and political relations in the Soviet Union and Eastern Europe have obvious implications for future levels of military spending. Whatever the final configuration of the Soviet Union, it is almost certain that a large share of its military budget will be shifted to serve civilian needs. Arms reductions talks, exemplified by the recently signed Strategic Arms Reduction Treaty (START), could lead to large cuts in real U.S. military spending.

For all of these reasons, it appears that funds for military spending are likely to be subject to much greater competition and scrutiny in the future than in much of the 1980s. While the shift in spending may stimulate the national economy, it will result in income and job loss in regions where military spending is a relatively large component of the economy unless policies to ease the transition to other types of economic activities are in place. The recent round of base closings exemplifies these regional impacts.

This paper summarizes findings regarding the economic impact of military spending on the Washington economy. We initially review the past and current importance of military-generated spending as a source of jobs and income in the Washington economy. Next, we analyze hypothetical military spending shocks and their likely impact on the state's economy. Finally, we review selected economic growth opportunities, especially regarding foreign trade, that might ease the transition to a more civilian-based economy.

\section{HISTORICAL IMPORTANCE OF MILITARY SPENDING TO THE STATE ECONOMY}

\section{Patterns of Recent Military Spending in Washington}

Washington is a state characterized by both large military installations and important companies with large military procurement contracts. After showing a pattern of steady growth from 1979 to 1983, total military spending in Washington has shown no upward trend since 1984. Not including Department of Energy spending at the Hanford weapons production facility, one measure of military spending went from about $\$ 3.2$ billion in 1978 to a peak of $\$ 6.2$ billion in 1983 and fell erratically to $\$ 5.8$ billion by 1987 (U.S. Department of Commerce, Bureau of the Census 1988). ${ }^{1}$

Total military spending in Washington can be divided into military procurement contracts plus total personnel-related payments. From the late 1970 s to the late 1980s, growth of the personnel payment category was quite steady. The large variation in total spending was due to variation in military procurement contracts. Total personnel payments are the sum of payrolls for active duty military person- 
nel, civilians employed by the military, payments to retired military personnel, and payments to the reserve and the National Guard. Procurement contracts are recorded by state of the prime contractor and in the year awarded, not in the year spent or by the location of any subcontractor.

\section{The Economic Model and Data}

The analysis in this paper is based on input-output analysis-the general equilibrium framework generally associated with the work of V. Leontief. (See e.g., Miller and Blair [1985] for basic principles of input-output analysis.) Leontieftype (input-output) models have been used to examine the effects of changing patterns and levels of military spending on economic activity in several previous studies. Leontief and Hoffenberg (1961) examined the effect of a cut in overall military spending on sectoral output and employment at the national level. Leontief et al. (1986) examined changes in output and employment for industries at the regional (multi-state) level under the assumption of a 20 percent decline in real military spending accompanied by a compensating increase in civilian purchases by the federal government. Finally, separate studies concerned with the economies of California and New Mexico have both used Leontief-type models to estimate the military's role in generating state economic activity (State of California 1988; Turpin, Adcock, and Lansford 1989).

In input-output models, total supply in an economy is determined by final demand. Shocks in final demand require changes in supply adequate to meet the changes in intermediate and final demand. The Leontief-type model is useful for understanding the impact of military spending on the Washington economy because military expenditures can be conveniently identified as an exogenous variable in such a model. ${ }^{2}$ Moreover, interindustry flow tables of the Washington State economy have been constructed from survey data and are highly regarded for their accuracy.

The model used here is based on the data collected for the 1982 Washington Input/Output Study (WIOS) by P. Bourque (1987) and on the IMPLAN model building procedure. The WIOS interindustry table consists of 51 industrial sectors and six final demand sectors for Washington State. In the model constructed for this study, the household sector was treated as an endogenous variable, and estimates of earnings and state personal income were used to obtain model closure (Bourque 1987). ${ }^{3}$ IMPLAN (Alward) also provided beginning estimates of military spending as a separate component of federal expenditure as opposed to a single measure of total federal spending in the original Bourque model. The analysis begins by identifying the direct purchases by the military from the 
Washington economy, as well as the payrolls for Department of Defense civilian and military employees in the state.

\section{Military Data}

Military-generated final demand for the Washington economy is composed of the following major components: 1) direct sales of goods and services to the military by Washington-based firms; 2) payrolls paid to federal government workers who are employed on military installations in Washington; and 3) payrolls paid to active duty personnel who are stationed in Washington. Note that for this analysis actual state military expenditures were estimated. Expenditure data is more difficult to obtain and less timely than procurement contract award data, but expenditure data better supports input-output analysis because it more accurately tracks interindustry flows.

The original estimates of military spending in the IMPLAN model were modified based on calculations and figures derived from the Defense Atlas for Washington and other Department of Defense publications relating to military procurement in Washington (U.S. Department of Defense 1985, 1984). Estimated military purchases by sector were then subtracted from the 1982 Bourque estimates of federal final demand to obtain estimates of federal civilian final demand. $^{4}$

For 1987 and for projections of growth in military demand, initial estimates were obtained from the Department of Defense RDEIMS system (U.S. Department of Defense 1987). ${ }^{5}$ In this information system, the Pentagon makes detailed (77 sectors at the two-digit level in the Bureau of Economic Analysis sectoring scheme) projections of estimated direct military expenditures at the national level for each of seven major accounts. An estimate of the spending for each account that will occur in each state is made by the Pentagon, based on recent historical averages of the state's share in that account by industrial sector.

Recent estimates of future military expenditures by sector for Washington were provided on computer disk by personnel in the Economic Analysis and Resource Planning Division in the Office of the Assistant Secretary of Defense (U.S. Department of Defense 1989). The Pentagon's data were then bridged to the 51 industrial sectors in the Washington (WIOS) model. To obtain the military final demand vector under the different expected spending scenarios, the 1991 industry pattern of military spending was benchmarked to 1988 real spending levels. These estimates were then uniformly shifted up or down, depending on the military spending scenario under investigation. 


\section{THE IMPACT OF MILITARY SPENDING IN WASHINGTON}

\section{Military Demand Relative to Other Final Demand Components}

Six components of final demand were defined: U.S. exports, foreign exports, Washington investment, Washington state and local government, federal civilian, and federal military (Table 1). In 1982, military purchases were the fourth largest component of final demand ( $\$ 4.5$ billion) and were three times the purchases for nonmilitary federal agencies ( $\$ 1.5$ billion). ${ }^{6}$ Sales to the rest of the United States was the largest category of demand (nearly $\$ 24$ billion).

Table 1 illustrates the impact on jobs in the Washington economy associated with a 10 percent across-the-board change for each component of final demand. For example, a 10 percent reduction in military spending in 1982 would have resulted in a total loss of more than 16,500 jobs. Approximately 10,000 of the jobs lost would be in the private sector, while 6,500 jobs would be in the form of military and civilian personnel reductions. In contrast, a 10 percent reduction in exports to the rest of the world would reduce total (all private sector) jobs by 23,600 .

The change in jobs resulting from a change of $\$ 100$ million in each category of final demand is also shown in Table 1. The pattern of military purchases produces fewer private sector jobs than any other category of demand, but creates more total jobs than any of the three private sector demand categories. For example, an increase of $\$ 100$ million in sales to the rest of the world would increase employment in Washington by slightly more than 2,600 jobs in the private sector. That same increase in spending by the military in Washington would increase labor demand in the private sector by only 1,536 jobs. However, as a result of its spending, the military provides 2,179 direct civilian jobs. When these jobs are added to private sector jobs, the military compares very favorably with any of the private sector demand categories as a generator of jobs. However, when compared to other forms of government spending, military spending is last in total number of jobs generated. This is consistent with the findings of other studies (Leontief and Hofferberg 1961) done at the national level.

\section{Military Spending, Income, and Jobs in Washington: 1982}

In 1982, total military purchases from the private sector in the Washington economy were estimated to be $\$ 3,361$ million, while payrolls for military personnel stationed in Washington and civilian personnel under contract to the military were $\$ 1,143$ million, for a total of $\$ 4,504$ million (Table 2 ). The sector showing 
TABLE 1

Components of Final Demand for

Washington Products and Their Impacts

on Job Changes in 1982

\begin{tabular}{|c|c|c|c|c|c|c|c|}
\hline \multirow{2}{*}{$\begin{array}{l}\text { Final } \\
\text { Demand } \\
\text { Component }\end{array}$} & \multirow{2}{*}{$\begin{array}{c}\text { Final } \\
\text { Demand } \\
\text { (Billions of } \$ \text { ) }\end{array}$} & \multicolumn{3}{|c|}{ Jobs per 10 Percent Change } & \multicolumn{3}{|c|}{ Jobs per $\$ 100$ Million Change } \\
\hline & & Private & Government & Total & Private & Govemment & Total \\
\hline U.S. exports & 23.957 & 70,651 & 0 & 70,651 & 2,949 & 0 & 2,949 \\
\hline Fore & & 23 & 0 & 23,594 & & 0 & 2,629 \\
\hline Investmen & 3.579 & 12,393 & 0 & 12,393 & 3,463 & 0 & 3,463 \\
\hline State-local government & 9.126 & 25,703 & 18,975 & 44,678 & 2,330 & 2,871 & 5,201 \\
\hline Federa & 1.507 & 3,847 & 4,771 & 8,618 & 1,669 & 2,356 & 4,025 \\
\hline Federal military & 4.504 & 10,048 & 6,520 & 16,568 & 1,536 & 2,179 & 3,715 \\
\hline
\end{tabular}

the largest sales to the military was aerospace, with shipbuilding second and construction a distant third.

Total employment due to military sales and payrolls in 1982 is also shown in Table 2. Private sector jobs derived from direct, indirect, and induced effects of military demand were estimated to be just under 98,200 (Table 2). In addition, 13,600 civilians worked directly for the military, and there were 51,600 active duty personnel in Washington. In 1982, Washington's total private employment was approximately $1,780,000$ jobs (Bourque 1987). Accordingly, private sector jobs derived from military spending and civilians directly employed by the military $(111,800$ workers) accounted for 6.3 percent of all jobs in the Washington economy in 1982 (active duty military excluded).

Additional detail on the distribution of private sector jobs associated with the pattern of demand established by the military can be seen in Table 2. Many of the jobs are in the service and distribution sectors, which largely results from the indirect effect of household spending associated with military payrolls and contractor payrolls. Both shipbuilding (14,989 jobs) and aerospace continue as major sectors of job location, but are overshadowed by jobs in services and wholesale and retail trade $(18,894$ jobs) that are indirectly linked to military-generated demand.

\section{Military Spending, Employment, and Jobs in Washington: 1987}

The composition and level of military demand in 1987 is also summarized in Table 2, where all 1987 military spending estimates are in 1982 dollars. The estimated level of spending by the military showed an increase of nearly $\$ 800$ million in real terms as compared to 1982 (Table 2). ${ }^{6}$ Some of the increase came in the form of increased military payrolls-nearly $\$ 200$ million-with the remainder consisting of increased purchases from Washington industries. 
The pattern of military demand in 1987 shows marked changes from the pattern of military spending in 1982. In 1982, aerospace was selling more to the military than to any other sector, with shipbuilding a close second. By 1987, shipbuilding had slipped to fourth place behind aerospace, other services, and electrical machinery. Military purchases from the other services and electrical machinery sectors showed tremendous growth from 1982 to 1987.

The number of jobs resulting from military spending increased to about 137,800 private sector jobs (Table 2) and about 209,500 total jobs (when active duty and direct civilian jobs are included) in 1987. From 1982 to 1987, the increase was roughly 39,600 new private sector jobs and 6,500 new active duty military and civilian military jobs. Total civilian employment in Washington for 1987 was roughly 2.1 million jobs (Washington State Office of the Forecast Council 1988). When active duty military jobs are excluded, military spending accounted for 7.3 percent of total employment. Because the corresponding figure for 1982 was 6.3 percent, it is clear that military-generated economic activity was an important source of job growth in the Washington economy from 1982 to 1987.

\section{THE IMPACT OF FUTURE RATES OF MILITARY SPENDING}

\section{The Hanford N-reactor and Its Impact on the Washington Economy}

Until recent years, the Hanford N-reactor and associated operations were an important generator of jobs and income in Washington. With direct employment at 6,300 jobs, it is estimated that in-state input purchases for the $\mathrm{N}$-reactor and the spending of $\mathrm{N}$-reactor payrolls accounted for another 4,600 jobs throughout the economy of the state.

In 1987, a decision was made not to restart the $\mathrm{N}$-reactor. Operations at the $\mathrm{N}$-reactor had been suspended following Chernobyl. This decision led to a decline in employment at Hanford to approximately 4,800 jobs in 1988-a reduction of 1,500 jobs. Accordingly, the job loss in relation to the "full operation phase," all other things being equal, was estimated to be 2,500 jobs, or 1,500 direct jobs and 1,000 indirect jobs throughout the rest of the economy.

The future phase-down schedule for the $\mathrm{N}$-reactor was somewhat uncertain at the time of this study. The scheduled shutdown projected that the $\mathrm{N}$-reactor facility would employ 3,600 workers in 1991, and the resulting level of total jobs throughout the state would be 6,300 jobs. Job loss from the 1988 base would be 2,100 jobs, or roughly 700 jobs annually. 
TABLE 2

Military Demand and Jobs

Due to Military Source Demand

by Economic Sector, 1982 and 1987

\begin{tabular}{|c|c|c|c|c|c|}
\hline \multirow{3}{*}{ State } & \multirow{3}{*}{ Economic Sector } & \multicolumn{2}{|c|}{ Demand } & \multicolumn{2}{|c|}{ Jobs } \\
\hline & & 1982 & 1987 & 1982 & 1987 \\
\hline & & \multicolumn{2}{|c|}{ (Millions of 1982 \$) } & & \\
\hline 1. & Field crops & 0.0 & 0.0 & 291 & 279 \\
\hline 2. & Vegetables and fruits & 0.0 & 0.0 & 490 & 384 \\
\hline 3. & Livestock products & 0.0 & 0.3 & 1,383 & 1,212 \\
\hline 4. & Other agriculture & 0.0 & 0.0 & 425 & 518 \\
\hline 5. & Fisheries & 0.0 & 2.0 & 320 & 444 \\
\hline 6. & Meat products & 10.1 & 0.0 & 154 & 142 \\
\hline 7. & Dairy products & 12.4 & 0.0 & 103 & 79 \\
\hline 8. & Canning and preserving & 37.1 & 13.6 & 438 & 231 \\
\hline 9. & Grain mills & 0.5 & 0.0 & 44 & 39 \\
\hline 10. & Beverages & 6.7 & 0.0 & 129 & 118 \\
\hline 11. & Other foods & 17.0 & 0.0 & 483 & 357 \\
\hline 12. & Textiles & 0.0 & 1.2 & 12 & 47 \\
\hline 13. & Apparel & 0.5 & 4.1 & 167 & 313 \\
\hline 14. & Mining & 4.7 & 0.3 & 187 & 125 \\
\hline 15. & Forestry & 0.0 & 0.0 & 49 & 43 \\
\hline 16. & Logging & 0.0 & 0.0 & 107 & 87 \\
\hline 17. & Sawmills & 0.0 & 0.0 & 193 & 167 \\
\hline 18. & Plywood & 0.0 & 0.0 & 40 & 37 \\
\hline 19. & Other wood products & 0.0 & 0.5 & 138 & 132 \\
\hline 20. & Furniture and fixtures & 1.5 & 2.9 & 148 & 174 \\
\hline 21. & Pulp mills & 0.0 & 0.0 & 3 & 2 \\
\hline 22. & Paper mills & 9.5 & 1.8 & 120 & 90 \\
\hline 23. & Paperboard and other paper & 10.1 & 0.3 & 191 & 123 \\
\hline 24. & Printing and publishing & 2.2 & 0.2 & 686 & 884 \\
\hline 25. & Industrial chemicals & 12.8 & 21.4 & 182 & 266 \\
\hline 26. & Other chemicals & 0.8 & 7.4 & 82 & 185 \\
\hline 27. & Petroleum & 124.4 & 37.7 & 102 & 79 \\
\hline 28. & Glass products & 2.1 & 0.3 & 64 & 37 \\
\hline 29. & Cement, stone, and clay & 0.0 & 2.7 & 157 & 218 \\
\hline 30. & Iron and steel & 0.4 & 4.0 & 91 & 145 \\
\hline 31. & Other nonfer. metals & 0.0 & 0.0 & 24 & 43 \\
\hline 32. & Aluminum & 0.0 & 9.9 & 34 & 89 \\
\hline 33. & Structural metal products & 7.1 & 4.9 & 189 & 169 \\
\hline 34. & Other fabric. metal products & 34.1 & 1.2 & 395 & 255 \\
\hline 35. & Nonelectrical motive equipment & 7.4 & 28.0 & 97 & 316 \\
\hline 36. & Machine tools and shops & 0.0 & 14.6 & 192 & 623 \\
\hline 37. & Nonelectrical industrial equipment & 2.4 & 186.7 & 88 & 2804 \\
\hline 38. & Electrical machinery & $7 \overline{5.4}$ & 563.5 & 989 & 6,880 \\
\hline 39. & Aerospace & 1400.0 & 1362.9 & 12,209 & 11,896 \\
\hline 40. & Motor vehicles & 3.7 & 49.9 & 20 & 189 \\
\hline 41. & Shipbuilding & 1079.9 & 515.6 & 14,984 & 7,196 \\
\hline 42. & Other manufacturing & 50.9 & 141.2 & 1,001 & 2,581 \\
\hline 43. & Transportation services & 72.9 & 62.9 & 2,502 & 2,689 \\
\hline 44. & Electrical companies & 13.9 & 20.4 & 435 & 558 \\
\hline 45. & Gas companies & 9.4 & 20.7 & 86 & 129 \\
\hline 46. & Other utilities & 2.1 & 0.0 & 353 & 381 \\
\hline 47. & Communications & 19.2 & 12.7 & 1,403 & 1.733 \\
\hline 48. & Construction & 173.6 & 203.2 & 3,529 & 4,138 \\
\hline 49. & Trade & 42.3 & 42.7 & 18,894 & 23,324 \\
\hline 50. & Financial services & 0.8 & 17.0 & 5,172 & 7,489 \\
\hline 51. & Other services & 113.2 & 591.8 & 28,587 & 57,343 \\
\hline \multirow[t]{2}{*}{52.} & Households & 1142.8 & 1334.2 & 0 & 0 \\
\hline & Total $^{1}$ & 4504.0 & 5285.0 & 98,162 & 137,784 \\
\hline
\end{tabular}

${ }^{1}$ In addition to purely private jobs, active military jobs were 51,600 in 1982 and 55,374 in 1987, while civilians directly employed by the military numbered 13,600 in 1982 and 16,307 in 1987. 
The above analysis does not consider the employment impact of the expanding waste management and environmental restoration program at Hanford. Estimated direct employment associated with this program by 1991 is 4,000 operations workers and 250 construction workers. The restoration and waste management program expansion should soften the economic impact of the $\mathrm{N}$ reactor shutdown. Thus, the estimated three-year economywide job loss resulting from the shutdown of 2,100 jobs would be balanced by 1,500 new jobs generated from growth of the waste management and environmental restoration program.

\section{The Impact of Future Military Spending in Washington}

Estimates of the pattern of military expenditures for 1991, as provided by the Office of the Secretary of Defense and presented in the RDEIMS system, were used to examine the implications of projected levels of military spending on the state economy (U.S. Department of Defense 1989). The pattern of expenditure projected in the RDEIMS system for Washington in 1991 was adjusted to reflect changes in real military spending assumed for four different spending scenarios (Table 3). The scenarios and the assumed increase or decrease in real spending over three years under each scenario are as follows: 1$)$ growth (3 percent real growth); 2 ) zero growth (0 percent real growth); 3 ) moderate decline (10 percent real decline); and 4) sharp decline (20 percent real decline).

The study base year was 1988 , with three-year projections to 1991 . The growth scenario was based on the assumption of no real growth in 1989, 1 percent real growth in 1990, and 2 percent real growth in 1991. The zero growth scenario assumed that military spending would increase at the rate of inflation. The moderate decline scenario called for holding military spending in Washington State at the same level of expenditures as in 1988. Assuming a 3 percent annual rate of inflation, this level of nominal expenditures would result in a 10 percent cut in real spending by 1991 . The moderate decline scenario assumption of an annual 3 percent decline in real expenditures best represents recent and probable immediate future patterns. The sharp decline scenario envisioned an actual spending cut of 10 percent over 1988 rates, which would result in a 20 percent reduction in real spending at the assumed rate of inflation over three years.

A total reduction of 11,090 jobs over a three-year period in strictly private Washington State employment was projected for the moderate decline scenario, as illustrated in Table 4. Losses in civilian military jobs were estimated at 1,600 jobs, and reductions in active duty personnel equaled 5,600 jobs for the same scenario. Including the 2,100 decline in jobs previously predicted for the Hanford $\mathrm{N}$-reactor shutdown, the moderate decline scenario would lead to a total reduction in Washington State employment of 20,300 total jobs $(14,700$ jobs excluding ac- 
TABLE 3

Direct Military Spending in Washington by Economic Sector, 1988 and Growth, Zero Growth, Moderate Decline, and Sharp Decline Spending Levels (Millions of 1982 \$)

\begin{tabular}{|c|c|c|c|c|c|c|}
\hline & \multirow[b]{2}{*}{ Economic Sector } & \multicolumn{5}{|c|}{ Spending Scenarios } \\
\hline & & 1988 & Growth & $\begin{array}{c}\text { Zero } \\
\text { Growth } \\
\end{array}$ & $\begin{array}{c}\text { Moderate } \\
\text { Decline }\end{array}$ & $\begin{array}{c}\text { Sharp } \\
\text { Decline }\end{array}$ \\
\hline 1. & Field crops & 0.0 & 0.0 & 0.0 & 0.0 & 0.0 \\
\hline 2. & Vegetables and fruits & 0.0 & 0.0 & 0.0 & 0.0 & 0.0 \\
\hline 3. & Livestock products & 1.1 & 1.1 & 1.1 & 1.0 & 0.8 \\
\hline 4. & Other agriculture & 0.0 & 0.0 & 0.0 & 0.0 & 0.0 \\
\hline 5. & Fisheries & 3.0 & 3.0 & 2.9 & 2.6 & 2.3 \\
\hline 6. & Meat products & 0.0 & 0.0 & 0.0 & 0.0 & 0.0 \\
\hline 7. & Dairy products & 0.0 & 0.0 & 0.0 & 0.0 & 0.0 \\
\hline 8. & Canning and preserving & 19.0 & 24.1 & 23.4 & 21.0 & 18.7 \\
\hline 9. & Grain mills & 0.0 & 0.0 & 0.0 & 0.0 & 0.0 \\
\hline 10. & Beverages & 0.0 & 0.0 & 0.0 & 0.0 & 0.0 \\
\hline 11. & Other foods & 0.0 & 0.0 & 0.0 & 0.0 & 0.0 \\
\hline 12. & Textiles & 1.0 & 1.0 & 0.9 & 0.8 & 0.7 \\
\hline 13. & Apparel & 5.7 & 6.6 & 6.4 & 5.7 & 5.1 \\
\hline 14. & Mining & 0.0 & 0.0 & 0.0 & 0.0 & 0.0 \\
\hline 15. & Forestry & 0.0 & 0.0 & 0.0 & 0.0 & 0.0 \\
\hline 16. & Logging & 0.0 & 0.0 & 0.0 & 0.0 & 0.0 \\
\hline 17. & Sawmills & 0.0 & 0.0 & 0.0 & 0.0 & 0.0 \\
\hline 18. & Plywood & 0.0 & 0.0 & 0.0 & 0.0 & 0.0 \\
\hline 19. & Other wood products & 0.0 & 0.0 & 0.0 & 0.0 & 0.0 \\
\hline 20. & Furniture and fixtures & 2.7 & 2.6 & 2.5 & 2.3 & 2.0 \\
\hline 21. & Pulp mills & 0.0 & 0.0 & 0.0 & 0.0 & 0.0 \\
\hline 22. & Paper mills & 2.8 & 2.7 & 2.6 & 2.4 & 2.1 \\
\hline 23. & Paperbd. and other paper & 0.0 & 0.0 & 0.0 & 0.0 & 0.0 \\
\hline 24. & Printing and publishing & 0.0 & 0.0 & 0.0 & 0.0 & 0.0 \\
\hline 25. & Industrial chemicals & 23.6 & 23.2 & 22.5 & 20.3 & 18.0 \\
\hline 26. & Other chemicals & 8.0 & 6.1 & 6.0 & 5.4 & 4.8 \\
\hline 27. & Petroleum & 39.5 & 42.2 & 41.0 & 36.9 & 32.8 \\
\hline 28. & Glass products & 0.0 & 0.0 & 0.0 & 0.0 & 0.0 \\
\hline 29. & Cement, stone, and clay & 2.7 & 1.8 & 1.7 & 1.6 & 1.4 \\
\hline 30. & Iron and steel & 4.0 & 2.9 & 2.9 & 2.6 & 2.3 \\
\hline 31. & Other nonfer. metals & 0.0 & 0.0 & 0.0 & 0.0 & 0.0 \\
\hline 32. & Aluminum & 10.8 & 10.7 & 10.4 & 9.3 & 8.3 \\
\hline 33. & Structural metal products & 4.9 & 4.8 & 4.7 & 4.2 & 3.7 \\
\hline 34. & Other fabric. metal products & 1.9 & 1.8 & 1.8 & 1.6 & 1.4 \\
\hline 35. & Nonelectrical motive equipment & 27.4 & 28.9 & 28.0 & 25.2 & 22.4 \\
\hline 36. & Machine tools and shops & 14.6 & 11.7 & 11.3 & 10.2 & 9.1 \\
\hline 37. & Nonelectrical industrial equipment & 203.2 & 237.2 & 230.2 & 207.2 & 184.2 \\
\hline 38. & Electrical machinery & 589.1 & 644.1 & 625.2 & 562.7 & 500.2 \\
\hline 39. & Aerospace & 1306.3 & 1217.7 & 1182.0 & 1063.8 & 945.6 \\
\hline 40. & Motor vehicles & 49.9 & 46.4 & 45.0 & 40.5 & 36.0 \\
\hline 41. & Shipbuilding & 516.5 & 520.2 & 504.9 & 454.4 & 403.9 \\
\hline 42. & Other manufacturing & 149.7 & 147.3 & 143.0 & 128.7 & 114.4 \\
\hline 43. & Transportation services & 85.1 & 91.0 & 88.4 & 79.5 & 70.7 \\
\hline 44. & Electrical companies & 21.3 & 24.5 & 23.8 & 21.4 & 19.0 \\
\hline 45. & Gas companies & 21.6 & 24.9 & 24.2 & 21.8 & 19.3 \\
\hline 46. & Other utilities & 0.0 & 0.0 & 0.0 & 0.0 & 0.0 \\
\hline 47. & Communications & 11.9 & 14.1 & 13.7 & 12.3 & 10.9 \\
\hline 48. & Construction & 213.8 & 256.2 & 248.7 & 223.8 & 199.0 \\
\hline 49. & Trade & 45.5 & 44.7 & 43.4 & 39.1 & 34.7 \\
\hline 50. & Financial services & 17.6 & 21.2 & 20.6 & 18.5 & 16.5 \\
\hline 51. & Other services & 621.4 & 687.5 & 667.3 & 600.6 & 533.9 \\
\hline \multirow[t]{2}{*}{52.} & Households & 1334.2 & 1374.5 & 1334.2 & 1200.8 & 1067.4 \\
\hline & Total & 5359.7 & 5526.7 & 5364.7 & 4828.2 & 4291.7 \\
\hline
\end{tabular}

Note: The growth scenario is based on a 1988 to 19913 percent real growth in military spending; no growth assumes no change in the level of real military spending; decline assumes a 10 percent cut; and sharp decline, a 20 percent cut in real military spending from 1988 to 1991. 
tive duty military) over a three-year period. In the case of the sharp decline scenario, the total job loss from all sources would be 42,300 , or an annual job loss of slightly less than 10,400 if only private sector and civilian government workers were counted.

An annual loss of 4,900 , or even 10,400 , jobs may seem to be very modest for a state economy where 2,100,000 workers were employed in 1988. A better perspective can be gained, however, by reexamining the role of military spending in the creation of jobs in the state economy from 1982 through 1987 . Over that five-year period, the Washington economy expanded by 273,000 jobs. The direct, indirect, and induced effects of increased real military spending accounted for an estimated 42,300 jobs, which consists of private sector $(39,600)$ and government civilian $(2,700)$ jobs or 15.5 percent of all new jobs created in 1982-1987.

Washington State will need roughly 60,000 new jobs annually to employ new entrants into the Washington labor market if recent trends hold. From 1982 to 1987, increased military spending provided about 8,500 new jobs annually. Under the moderate decline scenario, reductions in real military spending would result in a loss of nearly 4,900 jobs per year. Accordingly, the projected decline in spending under this scenario represents a swing in new job creation of roughly 13,400 jobs per year. Rather than being a strong engine for job growth, military spending rates will cause job reductions. If the economy is to remain at existing levels of unemployment, other sources of demand will be required to absorb an additional 13,400 workers per year.

\section{FOREIGN EXPORT SALES AS A POSSIBLE REPLACEMENT FOR MILITARY SALES}

There is a growing literature on specific avenues by which dollars saved in reduced military spending could be used to stimulate the economy (e.g., Adams and Gold 1987; Dumas 1986; Kennedy 1987; Oden 1988). For instance, some economists argue that resources now supporting military research could be shifted to more productive civilian research and development. More generally, resources employed in military activities would be freed up for other uses. For example, funds shifted from military spending might be used to lower deficit spending, thereby leading to lower interest rates and favorable foreign exchange rates which could stimulate investment and export growth. In this study, we did not look at prospects for redirecting military spending to stimulate nonmilitary sectors, but focussed on regional impacts. To explore what kind of regional economic expansion might balance the decline in military spending in Washington, foreign exports were examined. 
TABLE 4

Jobs Due to Military Spending in Washington

by Economic Sector, 1988, Growth, Zero Growth, Moderate Decline, and Sharp Decline Spending Levels

\begin{tabular}{|c|c|c|c|c|c|c|}
\hline & \multirow[b]{2}{*}{ Economic Sector } & \multicolumn{5}{|c|}{ Spending Scenarios } \\
\hline & & 1988 & Growth & $\begin{array}{c}\text { Zero } \\
\text { Growth }\end{array}$ & $\begin{array}{l}\text { Moderate } \\
\text { Decline }\end{array}$ & Decline \\
\hline 1. & Field crops & 289 & 301 & 293 & 263 & 234 \\
\hline 2. & Vegetables and fruits & 425 & 470 & 456 & 411 & 365 \\
\hline 3. & Livestock products & 1,260 & 1,310 & 1,271 & 1,144 & 1,017 \\
\hline 4. & Other agriculture & 528 & 557 & 540 & 486 & 432 \\
\hline 5. & Fisheries & 592 & 620 & 602 & 542 & 482 \\
\hline 6. & Meat products & 144 & 150 & 146 & 131 & 117 \\
\hline 7. & Dairy products & 80 & 84 & 81 & 73 & 65 \\
\hline 8. & Canning and preserving & 284 & 337 & 327 & 294 & 262 \\
\hline 9. & Grain mills & 40 & 42 & 41 & 37 & 33 \\
\hline 10. & Beverages & 120 & 125 & 122 & 109 & 97 \\
\hline 11. & Other foods & 363 & 377 & 366 & 330 & 293 \\
\hline 12. & Textiles & 41 & 41 & 40 & 36 & 32 \\
\hline 13. & Apparel & 373 & 409 & 397 & 357 & 318 \\
\hline 14. & Mining & 122 & 133 & 129 & 116 & 103 \\
\hline 15. & Forestry & 45 & 48 & 46 & 42 & 37 \\
\hline 16. & Logging & 90 & 96 & 93 & 84 & 74 \\
\hline 17. & Sawmills & 173 & 187 & 181 & 163 & 145 \\
\hline 18. & Plywood & 38 & 42 & 40 & 36 & 32 \\
\hline 19. & Other wood products & 126 & 135 & 131 & 118 & 105 \\
\hline 20. & Fumiture and fixtures & 170 & 173 & 168 & 151 & 135 \\
\hline 21. & Pulp mills & 2 & 3 & 2 & 2 & 2 \\
\hline 22. & Paper mills & 97 & 101 & 98 & 88 & 78 \\
\hline 23. & Paperbd. and other paper & 124 & 129 & 125 & 112 & 100 \\
\hline 24. & Printing and publishing & 901 & 947 & 919 & 827 & 736 \\
\hline 25. & Industrial chemicals & 288 & 287 & 279 & 251 & 223 \\
\hline 26. & Other chemicals & 195 & 179 & 174 & 156 & 139 \\
\hline 27. & Petroleum & 82 & 87 & 84 & 76 & 67 \\
\hline 28. & Glass products & 35 & 37 & 36 & 32 & 29 \\
\hline 29. & Cement, stone, and clay & 226 & 241 & 233 & 210 & 187 \\
\hline 30. & Iron and steel & 150 & 151 & 147 & 132 & 117 \\
\hline 31. & Other nonfer. metals & 45 & 49 & 48 & 43 & 38 \\
\hline 32. & Aluminum & 95 & 97 & 94 & 85 & 75 \\
\hline 33. & Structural metal products & 172 & 186 & 180 & 162 & 144 \\
\hline 34. & Other fabric. metal products & 269 & 286 & 277 & 250 & 222 \\
\hline 35. & Nonelectrical motive equipment & 310 & 326 & 317 & 285 & 253 \\
\hline 36. & Machine tools and shops & 632 & 593 & 576 & 518 & 461 \\
\hline 37. & Nonelectrical industrial equipment & 3,047 & 3,547 & 3,443 & 3,099 & 2,755 \\
\hline 38. & Electrical machinery & 7,189 & 7,854 & 7,624 & 6,862 & 6,099 \\
\hline 39. & Aerospace & 11,406 & 10,638 & 10,326 & 9,294 & 8,261 \\
\hline 40. & Motor vehicles & 190 & 177 & 172 & 155 & 138 \\
\hline 41. & Shipbuilding & 7,211 & 7,265 & 7,052 & 6,347 & 5,642 \\
\hline 42. & Other manufacturing & 2,725 & 2,709 & 2,629 & 2,366 & 2,103 \\
\hline 43. & Transportation services & 3,071 & 3,241 & 3,146 & 2,831 & 2,517 \\
\hline 44. & Electrical companies & 572 & 606 & 588 & 529 & 470 \\
\hline 45. & Gas companies & 133 & 145 & 140 & 126 & 112 \\
\hline 46. & Other utilities & 388 & 405 & 393 & 354 & 314 \\
\hline 47. & Communications & 1,756 & 1,861 & 1,806 & 1,626 & 1,445 \\
\hline 48. & Construction & 4,336 & 5,102 & 4,952 & 4,457 & 3,962 \\
\hline 49. & Trade & 23,817 & 24,810 & 24,083 & 21,675 & 19,267 \\
\hline 50. & Financial services & 7,646 & 8,126 & 7,887 & 7,099 & 6,310 \\
\hline \multirow[t]{2}{*}{51.} & Other services & 59,251 & 63,645 & 61,780 & 55,602 & 49,424 \\
\hline & Total & 141,666 & 149,466 & 145,084 & 130,576 & 116,068 \\
\hline
\end{tabular}

Note: The growth scenario is based on a 1988 to 19913 percent real growth in military spending; no growth assumes no change in the level of real military spending; decline assumes a 10 percent cut; and sharp decline a 20 percent cut in real military spending from 1988 to 1991. 
Foreign exports have several advantages as a future growth area for the state's economy because they are already a relatively large part of sales to final demand for Washington pioducts, and they have had high growth rates in recent years. Also, foreign exports may be more recession proof than other categories of final demand because downturns in the U.S. economy may have little impact on foreign demand for goods produced in the state. Furthermore, assuming that the ongoing General Agreement on Tariffs and Trade (GATT) negotiations are successful, the resulting lowering of barriers of entry to Washington products should lead to further opportunities for growth in foreign exports by Washington firms. Finally, foreign exports might in fact be stimulated as a consequence of the shift in funds from the military sector.

Growth in foreign exports was estimated to account for 58,213 new jobs from 1982 to 1987 , or 18 percent of all jobs that were generated in the state during that period. The sectors with the largest increases were trade and transportation services and aerospace.

\section{Projections of Washington Sales for Foreign Export}

Data compiled by Conway $(1987,1988)$, as well as data from various historic versions of the Washington input/output model (Bourque 1969, 1987; Bourque and Conway 1977), were used for the projections of foreign trade. These data were used to build trends and growth rates by sector for various time intervals, using either compound growth rates or linear regressions of the trends. These growth rates were then employed in projecting feasible future growth rates for foreign exports by sector.

A medium feasible growth rate was determined based on the average growth rate by sector of the most recent 10-year period (1977-1987). High and low projections for export growth by sector were based on the highest and lowest fiveyear growth rates for each sector during 1963-1982.

\section{Military and Export Scenarios Combined}

The study found that growth in exports can serve as a source of job creation in the future and can especially help to fill an employment gap created by cuts in military spending. Analysis suggests that the low export growth scenario would result in the generation of 27,000 jobs, and the medium export growth rate would generate slightly over 65,000 jobs in the three-year period from 1988 to 1991 . So it would seem that export growth would have the potential to offset most of the loss in military spending. 
It must be remembered, however, that the labor force is growing constantlyresulting in the need to create 194,800 jobs from 1988 to 1991 . Growth in exports may have to fill the natural increases in job needs, as well as job losses resulting from projected decline in military spending. For example, assuming a 10 percent cut in real military spending (the decline scenario) and a medium growth rate in export demand, growth in exports would provide 32 percent $(65,300$ jobs created out of total 194,800 jobs needed) of the jobs that must be created if the state unemployment rate is to be maintained at its current level. Even under the most optimistic export scenario, a job creation gap of slightly less than 130,000 jobs would exist under the most likely military spending scenario.

\section{SUMMARY AND CONCLUSIONS}

Several key points can be derived from this study of the effects of military spending on the Washington economy. First, military spending is important to the state's economy. Increased real military spending was an important source of economic growth and employment creation in Washington from 1982 to 1987.

A major portion of this study concerns the effect of simulated cuts in the levels of military spending on job creation in the Washington State economy. Model results indicate that cuts in military spending would shift military sales and payrolls from being a major source of job creation to a source of job loss. The study determined that high or even medium growth in foreign exports could help fill job losses that result from military spending cuts, but a very large job gap would remain.

The capacity of the Washington economy to generate the necessary rate of job growth to fill a potential job gap will primarily depend on national factors such as the continuing strength of the national economy. Exports to the rest of the United States are a major component of final demand for Washington products, and their continued growth will depend on the continued economic health of the U.S. economy in general. Expenditures for investment are also an important, yet volatile component of final demand. A strong national investment climate would lead to a high statewide demand for capital goods and the creation of many new jobs in Washington. It is quite likely that funds shifted from military spending would improve the national economy and so create the conditions necessary to compensate or even more than compensate for the job losses. Since this study focused on regional impacts, it did not explore the various paths by which such national economic stimulation might occur. However, the study did examine the foreign export sector, which is likely to benefit in some scenario of shifting budgets. 
While national-level variables will have a major influence on state economic performance, there is also a role for state-level action and policy as well. The ability of policy makers to react to decreases in military spending in the state could be strengthened in a number of ways. Clearly, a better information base detailing the role of military spending in the state's economy is necessary. This study is a first step in that direction; however, federal military spending in Washington should be monitored on a continuing basis. For instance, information about major military procurement contracts and military payrolls and studies of the likely effect on the state's employment picture of contract or installation termination would help predict who might be adversely affected when military spending in the state does decline.

Armed with information concerning the likely effects of cuts in military spending, policy makers can then strengthen the state's capacity to mitigate such reductions in federal military spending through advance notification, impact assistance programs, and expanded efforts to build capacity for training and retraining the current work force. By knowing the industries and occupations that will be hurt by spending cuts, policy makers could focus retraining and other economic development programs in an effective manner.

\section{ENDNOTES}

1. This measure of military spending included payments to retired military personnel. Payments to retired military were excluded in our analysis of the economic impact of military spending on the state economy. Moreover, this measure used contract awards, whereas the analysis used expenditure data.

2. The problems associated with assumptions inherent in input-output models are well known. Because of the assumption of fixed prices and fixed input requirements, the supply response is overestimated relative to a model where relative prices are allowed to change and input requirements are flexible. The estimates of output change and job change provided by the $(\mathrm{I} / \mathrm{O})$ model are properly regarded as upper bounds of the true estimates.

3. In other work examining the issue of closure of regional economic models, models using estimates of industry earnings and state personal income as the income base obtained the most accurate estimates of Leontief inverse coefficients (Holland and Wyeth 1989).

4. For the shipbuilding and aerospace sectors, the 1982 Bourque estimates of total federal spending were inconsistent with more accurate estimates of military spending. In these cases, the Bourque estimate of federal spending was changed to be more consistent with other estimates of military spending. 
5. FN-Defense Atlas data exists for both 1982 and 1987, but not for future years; RDEIMS system data existed in 1987 and beyond, but not in 1982 . Defense Atlas data from 1982 and RDEIM data from 1987 and 1991 are used because both were considered to be the most accurate source of data in a particular year.

6. The difference in total military spending in 1987 ( $\$ 5$ to $\$ 250$ billion) and military-generated final demand ( $\$ 4.504$ billion) is the military payroll for military and civilian employment. Further, one of the nonmilitary federal agencies is the Department of Energy, which funds the military-related activity of the Hanford N-reactor.

\section{REFERENCES}

Adams, Gordon, and David Gold. Defense Spending and the Economy: Does the Defense Dollar Make a Difference? Center on Budget and Policy Priorities: Washington, D.C., 1987.

Alward, Gregory S. IMPLAN version 2.0: Methods Used to Construct the 1982 Regional Economic Data Base. General Technical Report RM-000. U.S. Department of Agriculture, Forest Service, Rocky Mountain Forest and Range Experiment Station, Fort Collins, Colo., No Date.

Bourque, Philip J. "The Washington State Input/Output Study for 1982."

Graduate School of Business Administration, University of Washington, Seattle, Washington. March 1987.

"Detailed Input/Output Tables for Washington State, 1963."

Washington Agricultural Experiment Station Circular 508. Washington State University, Pullman, Washington. September 1969.

Bourque, Philip J., and Richard S. Conway, Jr. "The 1972 Washington Input/Output Study." Graduate School of Business Administration, University of Washington, Seattle, Washington. June 1977.

California Commission on State Finance. "Impact of Federal Expenditures on California." Sacramento, Calif., Fall 1988.

Conway, Richard S., Jr. "Current Conditions in Washington State Foreign Trade

and Investment." Seattle, Wash.: Dick Conway and Associates, August 1988.

Conway, Richard S., et al. "Foreign Exports and the Washington Economy."

Seattle, Wash.: Dick Conway and Associates, August 1987.

Dumas, Lloyd, Jr. The Overburdened Economy. Berkeley, Calif.: University of California Press, 1986.

Holland, David, and Peter Wyeth. "SAM Multipliers: Their Decomposition, Interpretation and Relationship to Input-Output Multipliers." Paper 
presented at the Western Regional Science Association Conference, San Diego, February 19-22, 1989.

Kennedy, Paul M. The Rise and Fall of the Great Powers. New York: Random House, 1987.

Leontief, Wassily, and Marvin Hofferberg. "The Economic Effects of Disarmament." Scientific American (April 1961).

Leontief, Wassily, Alison Morgan, Karen Polenske, David Simpson, and Edward Tower. "The Economic Impact-Industrial and Regional-of an Arms Cut (1965)." In Input-Output Economics, Ch. 10. 2nd ed. Edited by W. Leontief. New York: Oxford University Press, 1986.

Miller, Ronald E., and Peter O. Blair. Input-Output Analysis: Foundations and Extensions. Englewood Cliffs, NJ: Prentice-Hall, Inc., 1985.

Oden, Michael D. A Military Dollar Really is Different. Lansing, Mich.: Employment Research Associates, 1988.

Turpin, Annette, Larry Adcock, and Robert Lansford. "The Economic Impact of the Department of Energy on New Mexico, Fiscal Year 1987." Paper presented at the Western Regional Science Association Conference, San Diego, February 19-22, 1989.

U.S. Department of Commerce, Bureau of the Census. Federal Expenditures by State for Fiscal Year 1987, March 1988.

U.S. Department of Defense, Economic Analysis \& Resource Planning Division, Program Analysis and Evaluation. "Unpublished Data on Defense Spending in Washington State." Washington, D.C.: U.S. Government Printing Office, 1989.

State-Level Projections of Potential Defense Outlays and Employment an Introduction to RDEIMS. Washington, D.C.: U.S. Government Printing Office, 1987.

U.S. Department of Defense. Atlas/State Data Abstract for the United States Fiscal Year 1984. Washington, D.C.: Washington Headquarters Services Directorate for Information Operations and Reports, 1985.

. Prime Contract Awards by Region and State Fiscal Years 1981, 1982, 1983. Washington, D.C.: Washington Headquarters Services Directorate for Information Operations and Reports, 1984.

Washington State Office of the Forecast Council. State of Washington Economic and Revenue Forecast. no. 11(3). September 1988. 